\title{
Monoclonal Antibody 11D10 Anti-Idiotype Vaccine
}

National Cancer Institute

\section{Source}

National Cancer Institute. Monoclonal Antibody 11D10 Anti-ldiotype Vaccine. NCI

Thesaurus. Code C2606.

A vaccine consisting of a monoclonal antibody (MoAb) directed ag ainst an idiotype that mimics a human milk fat globule (HMFG) membrane epitope. Vaccination with monoclonal antibody 11D10 anti-idiotype vaccine induces anti-anti-idiotype antibodies (Ab3) that may react with breast cancer cell lines expressing the HMFG membrane epitope. 